\title{
Elaboration and Structural Investigation of Iron (III) Phosphate Glasses
}

\author{
Said Aqdim ${ }^{1,2 *}$, Malika Ouchetto ${ }^{3}$ \\ ${ }^{1}$ Laboratoire de Physique de Haute Energie et de l'Etat Condensé University Hassan II Ain Chock, Casablanca, Morocco \\ ${ }^{2}$ Laboratoire de Chimie Minérale, Département de Chimie, Faculty of \\ Sciences, Université Hassan II Ain Chock, Casablanca, Marocco \\ ${ }^{3}$ Laboratoire de Chimie du Solide Appliquée, Faculty of Science Rabat, University Mohammed V, Rabat, Morocco \\ Email: said_aq@yahoo.fr, mouchtto@fsr.ac.ma
}

Received November 14, 2013; revised December 8, 2013; accepted December 21, 2013

Copyright (C) 2013 Said Aqdim, Malika Ouchetto. This is an open access article distributed under the Creative Commons Attribution License, which permits unrestricted use, distribution, and reproduction in any medium, provided the original work is properly cited. In accordance of the Creative Commons Attribution License all Copyrights (C) 2013 are reserved for SCIRP and the owner of the intellectual property Said Aqdim, Malika Ouchetto. All Copyright (C) 2013 are guarded by law and by SCIRP as a guardian.

\begin{abstract}
The regular melting-quenching method allowed isolating very large vitreous domains within the ternary system $\mathrm{Li}_{2} \mathrm{O}$ $\mathrm{P}_{2} \mathrm{O}_{5}-\mathrm{Fe}_{2} \mathrm{O}_{3}$ at $1100^{\circ} \mathrm{C}$. The vitrification and crystallization effects are discussed in terms of phosphorus pentaoxide concentration $(\mathrm{mol} \%)$. In the course of the present study, we analyzed chemical durability along the glass domain and many sample glasses were isolated. We noticed that our compounds demonstrated very high chemical resistance to attack, even with very highly concentrated mineral acid solutions. This behavior can be assigned to the presence of poorly crystalline phases in these glasses, which tended to increase as the $\mathrm{Fe}_{2} \mathrm{O}_{3}$ content increased. This property is a prerequisite for many interesting industrial applications. XRD, IR spectroscopy and SEM micrographs allowed an efficient investigation of the structural changes versus composition within ternary diagrams. The results were found to be consistent with the regular structural changes of phosphate glasses.
\end{abstract}

Keywords: Phosphate Glasses; Glass Formation; Chemical Resistance; IR Spectroscopy; XRD; SEM

\section{Introduction}

The practical application of phosphate glasses is often limited by their poor chemical resistance. Recently, several phosphate glasses with high aqueous corrosion resistance have been reported [1]. Compared with conventional oxide glasses such as $\mathrm{SiO}_{2}$, phosphate glasses based on $\mathrm{P}_{2} \mathrm{O}_{5}$ are technologically important materials, primarily due to their superior physical properties such as low glass transition temperatures, chemical durability, low optical dispersions and relatively high thermal expansion coefficients. These properties make these glasses as potential candidates for many technological applications such as sealing materials, bioglasses, and electronic and optical devices, as laser hosts, nuclear waste glasses, glass-to-metal seals and as solid state electrolytes, etc., [1-6]. With their unusually high chemical durability and low processing temperature, iron phosphate glasses have been considered better for the vitrifying of nuclear

"Corresponding author. wastes than borosilicate glasses $[7,8]$. The aim of the present work firstly is to define the glass area in a ternary diagram and especially in the $\mathrm{Li}_{2} \mathrm{O}-\mathrm{Fe}_{2} \mathrm{O}_{3}-\mathrm{P}_{2} \mathrm{O}_{5}$. So we have explored that the introduction of iron oxide in the glass network can be up to $30 \mathrm{~mol} \%$ according to the conditions in which we worked, either at atmospheric pressure or at $1080^{\circ} \mathrm{C}-1100^{\circ} \mathrm{C}$. Secondly it is to investtigate the chemical resistance and structural properties of lithium-iron phosphate glasses and to relate the improve of chemical resistance to the structural change using IR spectroscopies, XR diffraction and SEM. Hence with increasing $\mathrm{Fe}_{2} \mathrm{O}_{3}$ content in the phosphate glass network, the P-O-P bands are replaced by more resistant Fe-O-P bands.

\section{Experimental}

The composition of the glasses was $\mathrm{xLi}_{2} \mathrm{O}-\mathrm{yFe} \mathrm{O}_{3}-\chi \mathrm{P}_{2} \mathrm{O}_{5}$, with $(\chi=(100-(\mathrm{x}+\mathrm{y}) ; \mathrm{mol} \%)$, obtained by the melting-quenching method at $1100^{\circ} \mathrm{C}$. An appropriate mixture of mixing compounds, i.e. $\mathrm{Li}_{2} \mathrm{CO}_{3}$, ferric oxides and 
$\left(\mathrm{NH}_{4}\right)_{2} \mathrm{HPO}_{4}$, was initially tempered at various temperatures between $100^{\circ} \mathrm{C}-600^{\circ} \mathrm{C}$ to achieve a preparation before glass preparation. The melts were achieved in alumina crucibles for about $15 \mathrm{~min}$ at $1080^{\circ} \mathrm{C} \pm 10^{\circ} \mathrm{C}$. The isolated glasses had regular shapes and an approximate size of $10 \mathrm{~mm}$ in diameter and $2 \mathrm{~mm}$ in thickness. The vitreous state was first evidenced from the shiny aspect and then confirmed from XRD patterns. Annealing of these glasses was performed at increasing temperatures in intervals of $100^{\circ} \mathrm{C}$. The first structural approach was made using X-ray diffraction which allowed us to follow the crystallization of the vitreous domain of $\mathrm{Li}_{2} \mathrm{O}-\mathrm{Fe}_{2} \mathrm{O}_{3}-\mathrm{P}_{2} \mathrm{O}_{5}$. The microstructure of sample glasses was characterized by scanning electron microy (SEM), equipped with a microanalyzer full system (EDXEDAX). The chemical durability of the glasses with the composition $\mathrm{x} \mathrm{Li} \mathrm{L}_{2} \mathrm{O}-\mathrm{y} \mathrm{Fe} \mathrm{Fe}_{2} \mathrm{O}_{3}-\chi \mathrm{P}_{2} \mathrm{O}_{5} ;(\chi-=(100-(\mathrm{x}+\mathrm{y}))$ were subjected to acid solutions using weak and strong concentrations of $\mathrm{HCl}$ and $\mathrm{H}_{2} \mathrm{SO}_{4}(0.1 \mathrm{~N}, 1 \mathrm{~N}$ and $10 \mathrm{~N})$. The duration of attack for some glasses and solution concentration continued for up to 30 days. The infrared (IR) spectra for each glass were measured between 400 and $1400 \mathrm{~cm}^{-1}$ using $\mathrm{mX}-1$ and NIC-3600 FTIR spectrometers. Samples were prepared by pressing a mixture of about $2 \mathrm{mg}$ of glass powder with $100 \mathrm{mg}$ of anhydrous $\mathrm{KBr}$ powder.

\section{Results}

In the system $\mathrm{Li}_{2} \mathrm{O}-\mathrm{P}_{2} \mathrm{O}_{5}$, transparent glasses were prepared for $0 \leq \mathrm{x} \leq 62$ (Figure 1). These values are in agreement with published results $[9,10]$, but they are superior to those given by other authors $[11,12]$. This was probably caused by the different experimental conditions (temperature of melting, speed of tempering, etc.)
[13]. In the binary system $\mathrm{Fe}_{2} \mathrm{O}_{3}-\mathrm{P}_{2} \mathrm{O}_{5}$, the substitution of $\mathrm{P}_{2} \mathrm{O}_{5}$ with $\mathrm{Fe}_{2} \mathrm{O}_{3}$ led to black glasses that were not hygroscopic for ironoxide contents between 0 and $30 \mathrm{~mol} \%$ (Figure 1). Ternary glasses rich in $\mathrm{Fe}_{2} \mathrm{O}_{3}$ content had a dark brown color which became more and more brown clear as the lithium oxide content increased and the $\mathrm{Fe}_{2} \mathrm{O}_{3}$ content decreased. The demarcation of the glassy zone within the ternary diagram $\mathrm{Li}_{2} \mathrm{O}-\mathrm{Fe}_{2} \mathrm{O}_{3}-\mathrm{P}_{2} \mathrm{O}_{5}$ is given by the following limits: $0 \leq \mathrm{x} \leq 62 ; 0 \leq \mathrm{y} \leq 30 ; 36$ $\leq \chi \leq 1 ;(\mathrm{mol} \%)$ (Figure 1).

\subsection{Annealing Temperature}

The annealing of the ternary glasses was performed by increasing the temperature in intervals of $100^{\circ} \mathrm{C}$. An increase in the lithium oxide modifier led to a slight increase in the crystallization temperature. For the glasses with the composition $x \mathrm{Li}_{2} \mathrm{O}-5 \mathrm{Fe}_{2} \mathrm{O}_{3}-\chi \mathrm{P}_{2} \mathrm{O}_{5}$, the crystallization temperature increased from $390^{\circ} \mathrm{C}$ to $480^{\circ} \mathrm{C}$ for $\mathrm{x}$ $=30$ to $\mathrm{x}=50$, respectively (Figure 2 [14]. On the other hand, Figure 3 shows that an increase in the $\mathrm{Fe}_{2} \mathrm{O}_{3}$ content in the glasses $\mathrm{xLi}_{2} \mathrm{O}-\mathrm{yFe} \mathrm{O}_{2} \mathrm{O}_{3}-\chi \mathrm{P}_{2} \mathrm{O}_{5}($ with $\mathrm{x} / \chi=0.54)$ caused a quick increase in the value of the crystallization temperature from $120^{\circ} \mathrm{C}$ for a binary glass $\mathrm{Li}_{2} \mathrm{O}-\mathrm{P}_{2} \mathrm{O}_{5}(\mathrm{y}$ $=0)$ to $540^{\circ} \mathrm{C}$ for $\mathrm{y}=18[6,15]$. Figure 4 shows for the binary glasses $\mathrm{Fe}_{2} \mathrm{O}_{3}-\mathrm{P}_{2} \mathrm{O}_{5}$ that the variation in the annealing temperature (Tc) according to the $\mathrm{Fe}_{2} \mathrm{O}_{3}$ contenthad a maximum at $700^{\circ} \mathrm{C}$ for the glass composition 16 $\mathrm{Fe}_{2} \mathrm{O}_{3}-84 \mathrm{P}_{2} \mathrm{O}_{5}$ and was constant when the $\mathrm{Fe}_{2} \mathrm{O}_{3}$ content was more than $\mathrm{y}=25[16,17]$.

\subsection{X-Ray Diffraction}

The X-ray diffraction spectra show that the crystallized glasses seemed to be similar to the closest crystalline

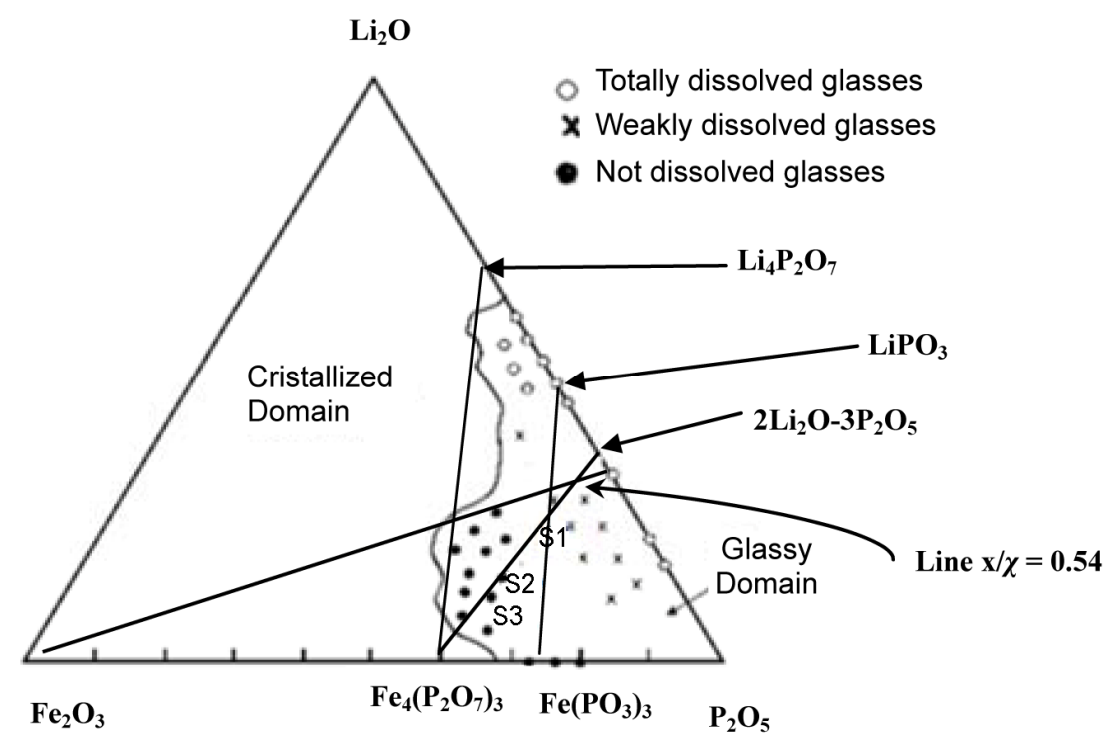

Figure 1. Extended from the vitreous field within the ternary diagram of $\mathrm{Li}_{2} \mathrm{O}-\mathrm{P}_{2} \mathrm{O}_{5}-\mathrm{Fe}_{2} \mathrm{O}_{3}$ to $1080^{\circ} \mathrm{C}-1100^{\circ} \mathrm{C}$. 


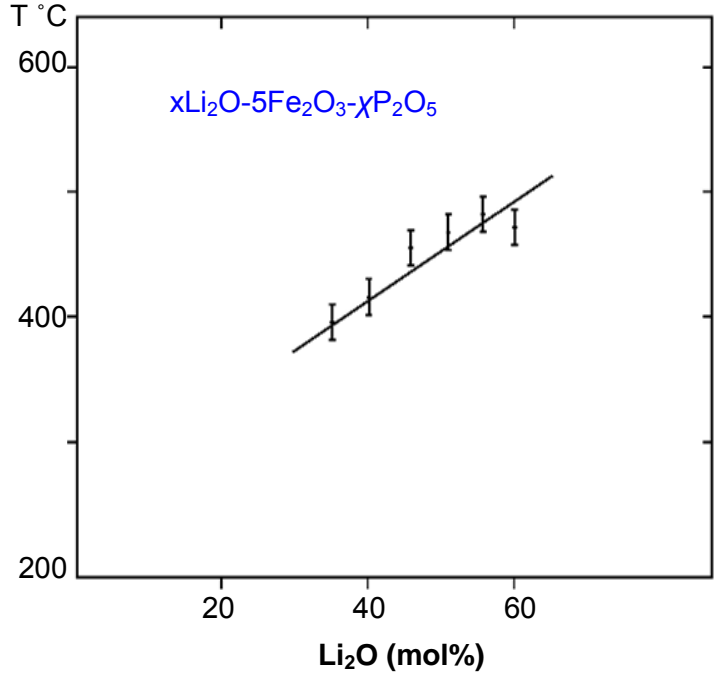

Figure 2. Crystallization temperature of iron phosphate glasses with the composition $\mathrm{xLi}_{2} \mathrm{O}-5 \mathrm{Fe}_{2} \mathrm{O}_{3}-\chi \mathrm{P}_{2} \mathrm{O}_{5}$.

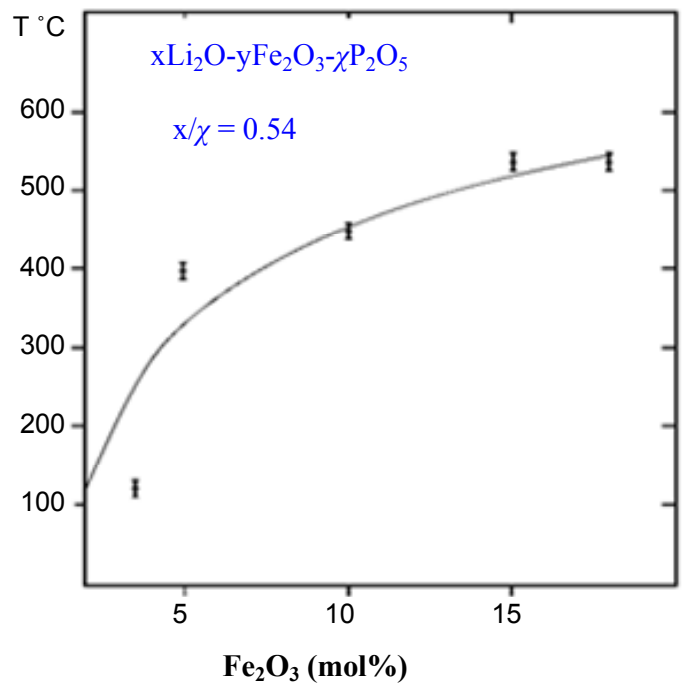

Figure 3. Crystallization temperature of iron phosphate glasses for the ratio $\mathrm{Li}_{2} \mathrm{O} / \mathrm{P}_{2} \mathrm{O}_{5}=0.54$.

phases within the ternary diagram of $\mathrm{Li}_{2} \mathrm{O}-\mathrm{Fe}_{2} \mathrm{O}_{3}-\mathrm{P}_{2} \mathrm{O}_{5}$. The X-ray diffraction spectra of crystallized glasses with the composition $\times \mathrm{Li}_{2} \mathrm{O}-5 \mathrm{Fe}_{2} \mathrm{O}_{3}-\chi \mathrm{P}_{2} \mathrm{O}_{5}$ were similar to those of the $\mathrm{LiPO}_{3}$ glasses in the neighborhood of $\chi=50$ (Figure 5(a)) and those of $\mathrm{Li}_{4} \mathrm{P}_{2} \mathrm{O}_{7}$ for $\chi \leq 45$ (Figure 5(b)). Figure 6 shows the structural evolution for the ternary glasses $\mathrm{x} . \mathrm{Li}_{2} \mathrm{O}-\mathrm{y} \cdot \mathrm{Fe}_{2} \mathrm{O}_{3}-\chi \mathrm{P}_{2} \mathrm{O}_{5}$ localized along the line attributed to the ratio $\mathrm{Li}_{2} \mathrm{O} / \mathrm{P}_{2} \mathrm{O}_{5}=0.54$. We noted a mixture of metaphosphate phases for an $\mathrm{Fe}_{2} \mathrm{O}_{3}$ content $\leq$ 5, and pyrophosphate phases with an $\mathrm{Fe}_{2} \mathrm{O}_{3}$ content $\geq 15$ $[1,18,19]$. The $\mathrm{x}$-ray diffraction spectra for crystallized glasses of the binary system y $\mathrm{Fe}_{2} \mathrm{O}_{3}-(100-\mathrm{y}) \mathrm{P}_{2} \mathrm{O}_{5}$ (Figure 7) seemed to favor the form of phases similar to $\mathrm{Fe}\left(\mathrm{PO}_{3}\right)_{3}$ which become more obvious when the $\mathrm{Fe}_{2} \mathrm{O}_{3}$ content increased to $\mathrm{y}=25$.

\subsection{Chemical Stability}

Binary glasses of the composition $\mathrm{yFe}_{2} \mathrm{O}_{3}-(100-\mathrm{y}) \mathrm{P}_{2} \mathrm{O}_{5}$ had excellent chemical resistance toward chemical aggressors when the iron oxide content was increased in the glassy network. These glasses were immersed in weak and strong acid solutions of $\mathrm{HCl}(0.1 \mathrm{~N}, 1 \mathrm{~N}$ and $10 \mathrm{~N})$ and $\mathrm{H}_{2} \mathrm{SO}_{4}(0.1 \mathrm{~N}, 1 \mathrm{~N}$ and $10 \mathrm{~N})$ for 30 days. Their weights before and after attack were practically the same. Figure 1 shows that the iron ternary glasses had relatively weak chemical resistance to chemical aggressors when the $\mathrm{Li}_{2} \mathrm{O}$ content was increased in the glass network. However, when this value decreased, the iron ternary glasses became resistant, even with a low $\mathrm{Fe}_{2} \mathrm{O}_{3}$ content $[1,5,20-22]$.

\subsection{Infrared Spectra and SEM Analysis}

The IR spectra of the binary $\mathrm{yFe}_{2} \mathrm{O}_{3}-(1-\mathrm{y}) \mathrm{P}_{2} \mathrm{O}_{5}$ are shown in Figure 8. With an increase in the $\mathrm{Fe}_{2} \mathrm{O}_{3}$ content, both the bands observed at 1290 and $785 \mathrm{~cm}^{-1}$ and the band at $940 \mathrm{~cm}^{-1}$ shifted to lower frequencies and the intensities decreased by changing the $\mathrm{Fe}_{2} \mathrm{O}_{3}$ content from 10 to $28 \mathrm{~mol} \%$. The bands at $1290 \mathrm{~cm}^{-1}$ assigned to $v_{\text {as }}$ $\mathrm{PO}_{2}$ disappeared from the spectrum, while the band at $725 \mathrm{~cm}^{-1}$ assigned to $v_{\mathrm{s}}$ POP became a simple shoulder. The intensity of the IR band at $1070 \mathrm{~cm}^{-1}$ assigned to $v_{\mathrm{s}}$ $\mathrm{PO}_{2}$ increased broadly [1,23-25]. The IR spectra observed with the composition $\mathrm{xLi}_{2} \mathrm{O}-5 \mathrm{Fe}_{2} \mathrm{O}_{3}-\chi \mathrm{P}_{2} \mathrm{O}_{5}$ are shown in Figure 9. When lithium oxide was added to the glass network, this last one is depolymerized to the shorter group units, in agreement with results published by Ouchetto and al. [1,11,20-24]. The IR spectra show that the band at $1280 \mathrm{~cm}^{-1}$ assigned to $v_{\mathrm{as}} \mathrm{PO}_{3}$ decreased and shifted to lower frequencies when we shift away from the $\mathrm{P}_{2} \mathrm{O}_{5}$ point. On the other hand, the intensity of the band at $1100-1120 \mathrm{~cm}^{-1}$ was assigned to increased $v_{\mathrm{s}} \mathrm{PO}_{2}$ when

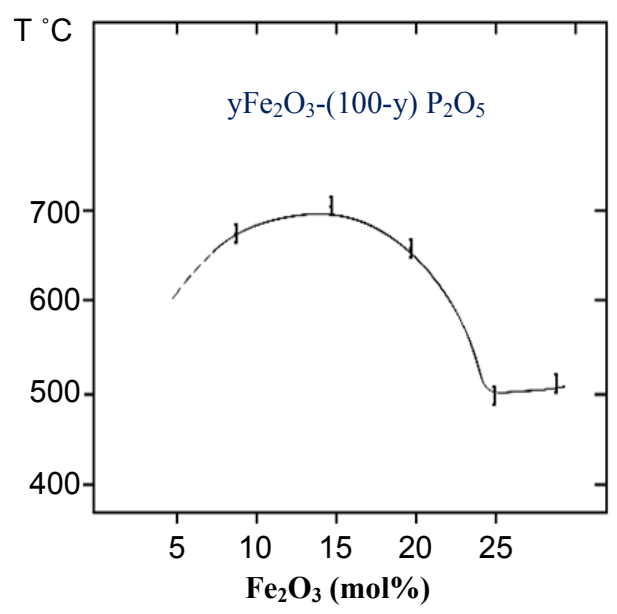

Figure 4. Crystallization temperatures of iron phosphate glasses with the composition $\mathrm{yFe}_{2} \mathrm{O}_{3}-(100-y) \mathrm{P}_{2} \mathrm{O}_{5}$. 


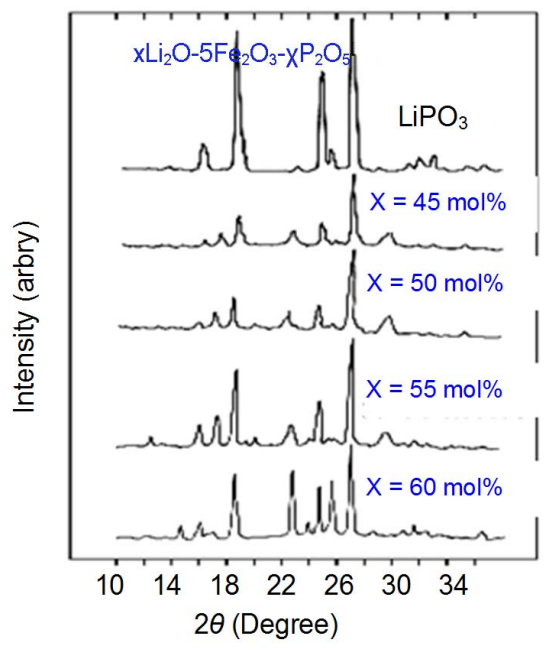

(a)

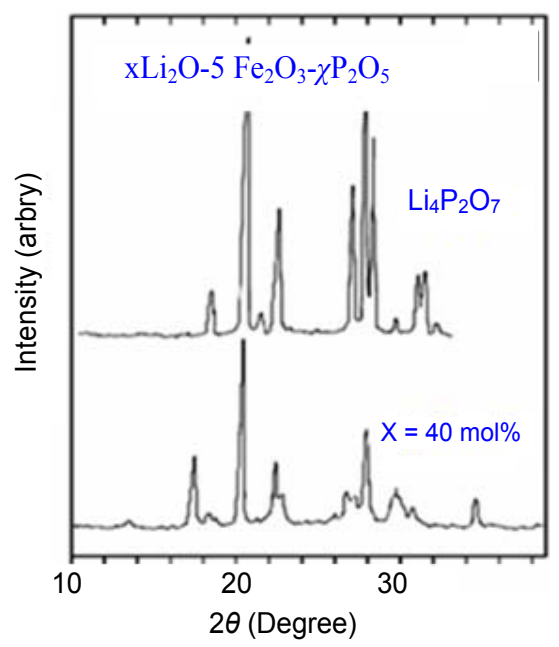

(b)

Figure 5. X-ray diffraction of crystallized lithium-iron phosphate glasses with the composition $x \mathrm{xi}_{2} \mathrm{O}-5 \mathrm{Fe}_{2} \mathrm{O}_{3}-\chi \mathrm{P}_{2} \mathrm{O}_{5}$ compared with compounds $\mathrm{LiPO}_{3}(\mathrm{a})$ and $\mathrm{Li}_{4} \mathrm{P}_{2} \mathrm{O}_{7}$ (b).

the lithium oxide content increased. This increase in the $\mathrm{Li}_{2} \mathrm{O}$ content breaks P-O-P bonds and increases the number of non-oxygen bridges. The IR spectra observed with these glasses were similar to the spectra of the $\mathrm{xLi}_{2} \mathrm{O}$ $\chi \mathrm{P}_{2} \mathrm{O}_{5}$ family, which can be explained by a similar structural evolution $[1,10,12]$. Figures $\mathbf{1 0}$ and $\mathbf{1 1}$ show the IR spectra of glasses with the compositionsx $\mathrm{Li}_{2} \mathrm{O}-\mathrm{yFe}_{2} \mathrm{O}_{3}$ $\chi \mathrm{P}_{2} \mathrm{O}_{5}$ with $\mathrm{x} / \chi=0.54$ and $\mathrm{xLi}_{2} \mathrm{O}-\mathrm{yFe}_{2} \mathrm{O}_{3}-60 \mathrm{P}_{2} \mathrm{O}_{5}$, respectively. The analysis of these spectra showed that the band at $1290 \mathrm{~cm}^{-1}$ assigned to $v_{\text {as }} \mathrm{PO}_{2}$ shifted toward lower frequencies and decreased when the iron oxides content increased. It disappeared completely when the $\mathrm{Fe}_{2} \mathrm{O}_{3}$ content was $>25$. On the other hand, the band at $1070-1100 \mathrm{~cm}^{-1}$ assigned to $v_{\mathrm{s}} \mathrm{PO}_{2}$ with an iron oxide content of $10 \leq y \leq 30$ seemed to form an envelope of the spectra of the compound $\mathrm{LiFeP}_{2} \mathrm{O}_{7}$ (Figure 10), $[1,19,23$, 25-27]. These results suggest that these glasses were

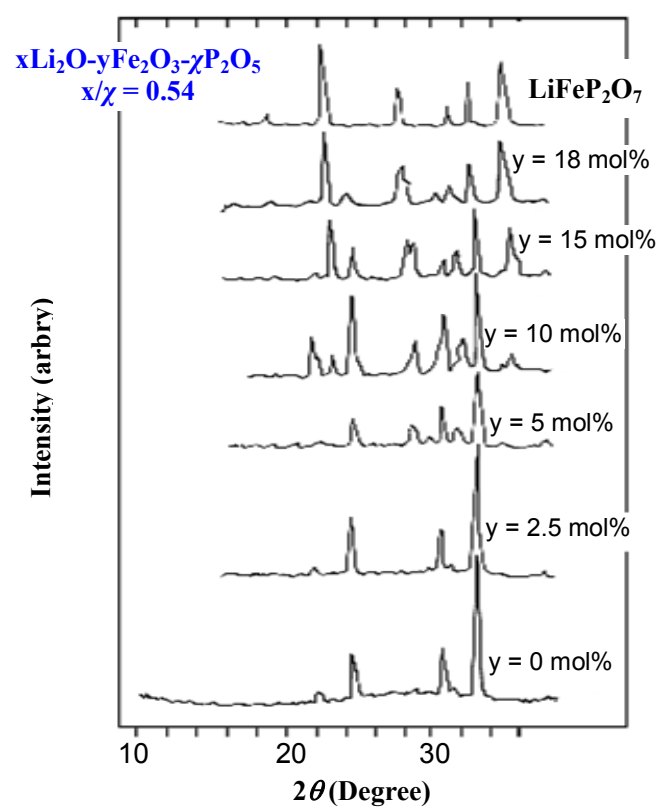

Figure 6. X-ray diffraction after heat treatment at crystallization temperatures for lithium-iron phosphate glasses with the composition $x \mathrm{Li}_{2} \mathrm{O}-\mathrm{yFe}_{2} \mathrm{O}_{3}-\chi \mathrm{P}_{2} \mathrm{O}_{5}$ with $\mathrm{x} / \chi=0.54$.

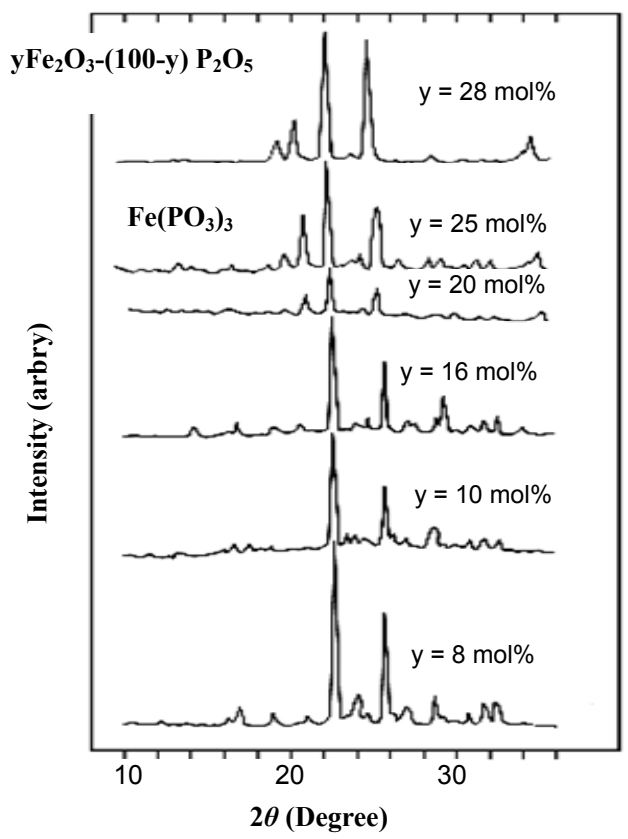

Figure 7. $\mathrm{X}$-ray diffraction of crystallized iron phosphate glasses of the binary system $\mathrm{yFe}_{2} \mathrm{O}_{3}-(100-y) \mathrm{P}_{2} \mathrm{O}_{5}$.

formed, in general, by unit groups of pyrophosphate when the $\mathrm{Fe}_{2} \mathrm{O}_{3}$ content increased. Figure 12 shows SEM micrographs of sample $\mathrm{S} 1$ with the composition $30 \mathrm{Li}_{2} \mathrm{O} \cdot 10 \mathrm{Fe}_{2} \mathrm{O}_{3} \cdot 60 \mathrm{P}_{2} \mathrm{O}_{5}$ as well as micrographs of $\mathrm{S} 2$ and $\mathrm{S} 3$ with the composition $20 \mathrm{Li}_{2} \mathrm{O} \cdot 20 \mathrm{Fe}_{2} \mathrm{O}_{3} \cdot 60 \mathrm{P}_{2} \mathrm{O}_{5}$ and $10 \mathrm{Li}_{2} \mathrm{O} \cdot 30 \mathrm{Fe}_{2} \mathrm{O}_{3} \cdot 60 \mathrm{P}_{2} \mathrm{O}_{5}$, respectively. The SEM micrograph of S1 (Figure 12(a)) shows an approximately homogenous glassy phase. However, SEM analysis 


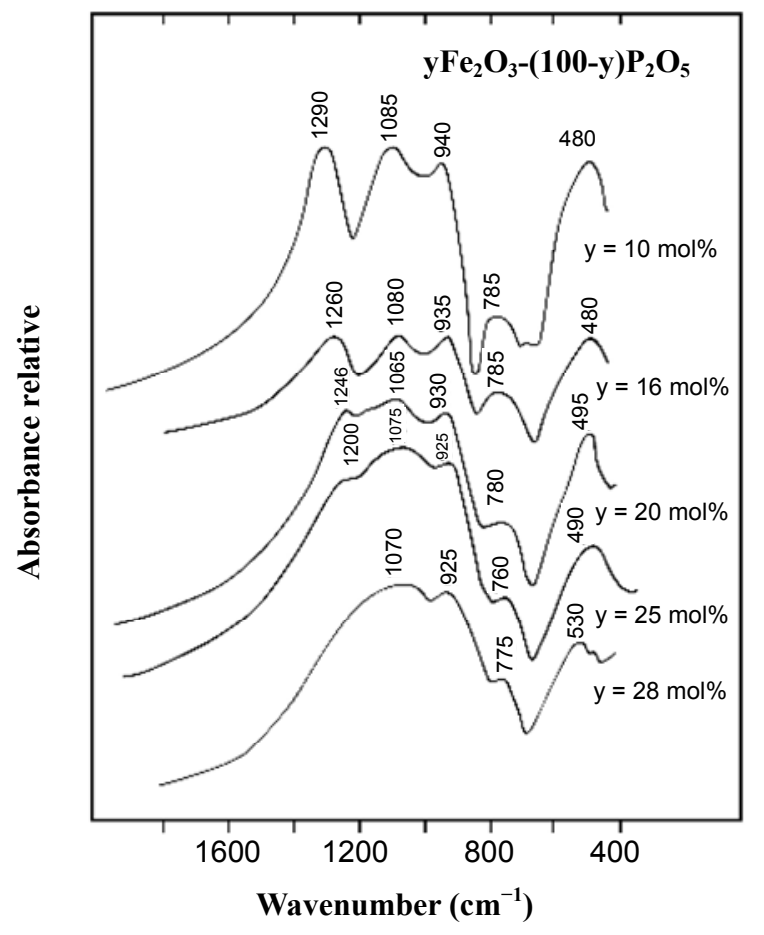

Figure 8. IR spectra of iron phosphate glasses with the composition $\mathrm{yFe}_{2} \mathrm{O}_{3}-(100-\mathrm{y}) \mathrm{P}_{2} \mathrm{O}_{5}$.

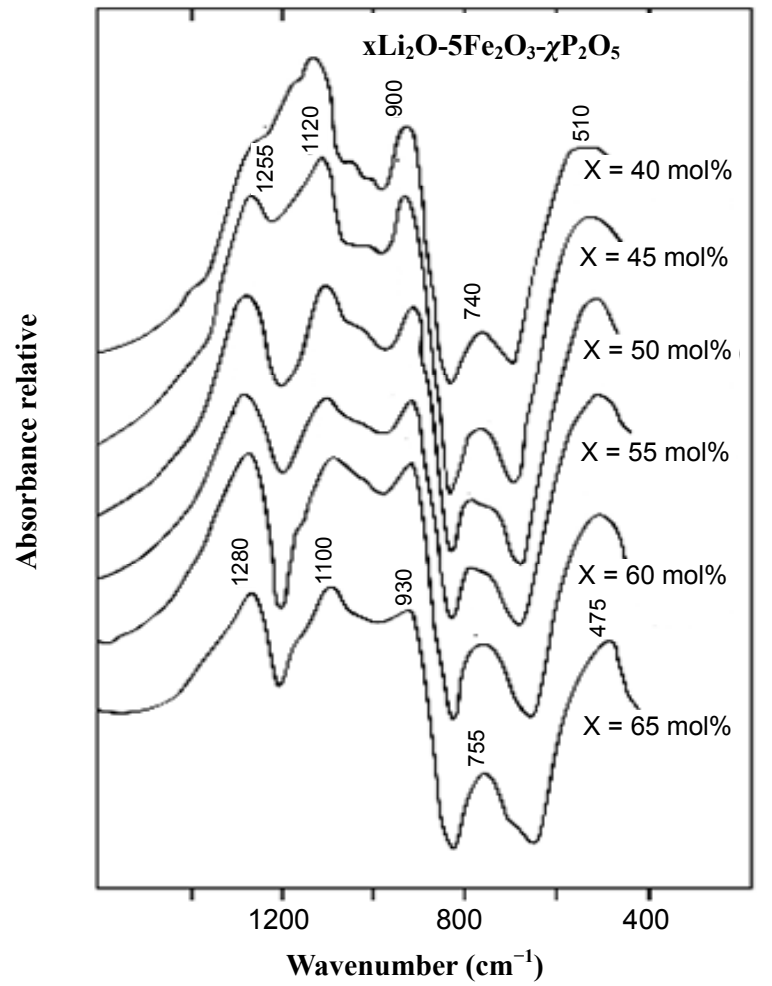

Figure 9. IR spectra of iron phosphate glasses with the composition $x \mathrm{Li}_{2} \mathrm{O}-5 \mathrm{Fe}_{2} \mathrm{O}_{3}-\chi \mathrm{P}_{2} \mathrm{O}_{5}$.

indicated the presence of crystalline phases in samples $\mathrm{S} 2$ and $\mathrm{S} 3$ which had an $\mathrm{Fe}_{2} \mathrm{O}_{3}$ content $\geq 20(\mathrm{~mol} \%)$,

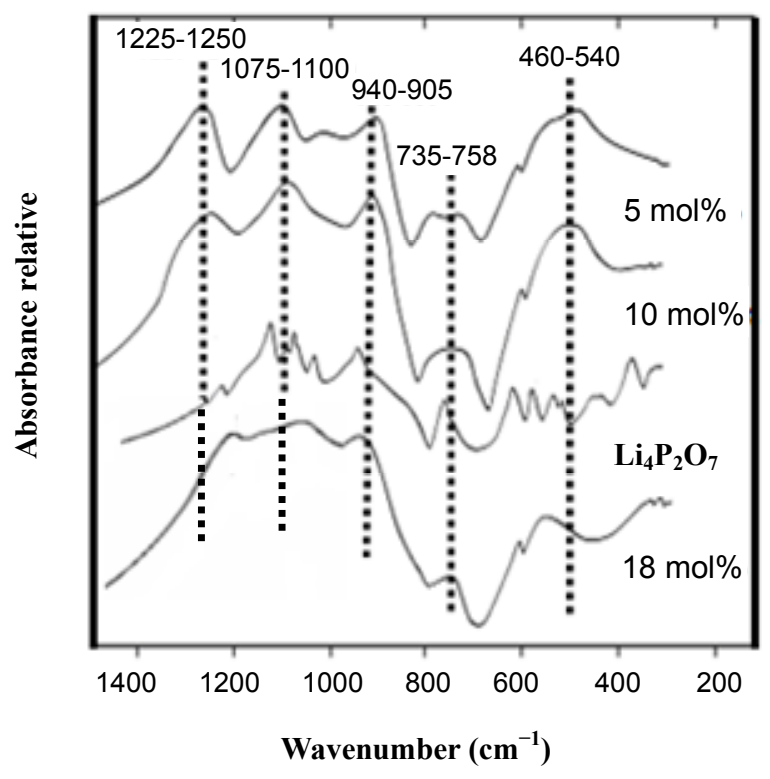

Figure 10. IR spectra of lithium-iron phosphate glasses with the composition $\mathrm{xLi}_{2} \mathrm{O}-\mathrm{yFe} \mathrm{O}_{2} \mathrm{O}_{3}-\chi \mathrm{P}_{2} \mathrm{O}_{5}$ with $\mathrm{x} / \chi=0.54$.

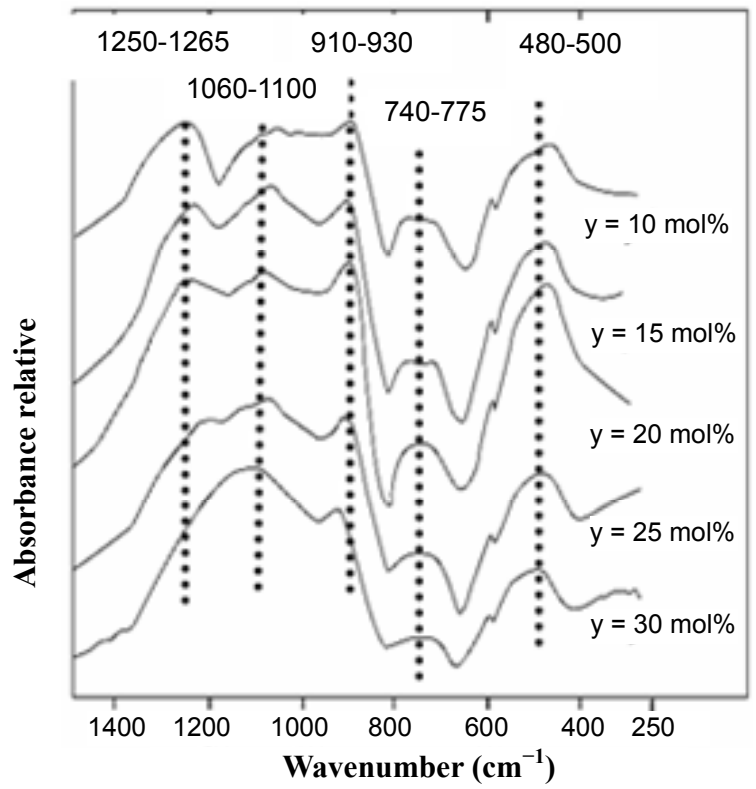

Figure 11. IR spectra of lithium-iron phosphate glasses with the composition $(40-y) \mathrm{Li}_{2} \mathrm{O}-\mathrm{yFe}_{2} \mathrm{O}_{3}-60 \mathrm{P}_{2} \mathrm{O}_{5}$.

shown in Figures 12(b) and (c), respectively. Hence, it seems that with an increasing $\mathrm{Fe}_{2} \mathrm{O}_{3}$ content, the crystallization tendency is enhanced; the $\mathrm{LiFeP}_{2} \mathrm{O}_{7}$ and $\mathrm{Fe}\left(\mathrm{PO}_{3}\right)_{3}$ phases almost certainly crystallized in these glasses.

\section{Discussion}

The regular melting-quenching method allowed for isolating a very large vitreous domain within the ternary system $\mathrm{Li}_{2} \mathrm{O}-\mathrm{P}_{2} \mathrm{O}_{5}-\mathrm{Fe}_{2} \mathrm{O}_{3}$. An increase in the lithium oxide content in phosphate glasses caused a small increase 


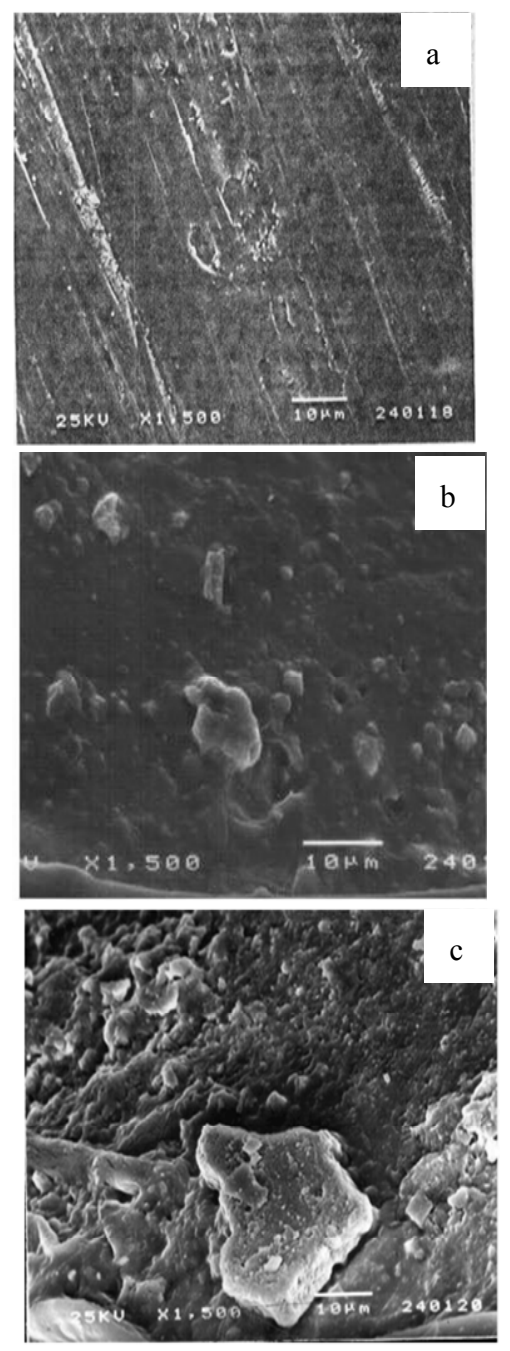

Figure 12. SEM micrographs of samples with the composition $(40-y) \mathrm{Li}_{2} \mathrm{O}-\mathrm{yFe}_{2} \mathrm{O}_{3}-60 \mathrm{P}_{2} \mathrm{O}_{5}$.

in the crystallization temperature. However, an increase in the $\mathrm{Fe}_{2} \mathrm{O}_{3}$ content in phosphate glasses initiated an important increase in the crystallization temperature. This was more significant for the binary glasses $\mathrm{Fe}_{2} \mathrm{O}_{3}$ $\mathrm{P}_{2} \mathrm{O}_{5}$ where the crystallization temperature reached $700^{\circ} \mathrm{C}$ for the sample with the composition

$16 \mathrm{Fe}_{2} \mathrm{O}_{3} \cdot 84 \mathrm{P}_{2} \mathrm{O}_{5}$. The $\mathrm{X}$-ray diffraction spectra indicate the structural evolution of crystallized glasses inthe ternary diagram of $\mathrm{Li}_{2} \mathrm{O}-\mathrm{Fe}_{2} \mathrm{O}_{3}-\mathrm{P}_{2} \mathrm{O}_{5}$. The resultsshow that when the composition of the vitreous zone was moved away from the $\mathrm{P}_{2} \mathrm{O}_{5}$ point, the structure evolved toward one with a known crystallized composition neighborhood, $\mathrm{LiPO}_{3}, \mathrm{Fe}\left(\mathrm{PO}_{3}\right)_{3}, \mathrm{Li}_{4} \mathrm{P}_{2} \mathrm{O}_{7}, \mathrm{LiFeP}_{2} \mathrm{O}_{7}$. When the iron oxide content increased in the glass network, both binary and ternary glasses showed excellent chemical resistance toward chemical aggressors. However, an increase in the $\mathrm{Li}_{2} \mathrm{O}$ content led to poor chemical resistance. The IR spectra for glasses with the composition $x \mathrm{Li}_{2} \mathrm{O}-5 \mathrm{Fe}_{2} \mathrm{O}_{3^{-}}$ $\chi \mathrm{P}_{2} \mathrm{O}_{5}$ show that an increase in the lithium oxide content in the glass network induced the birth of small units,more than in the binary system $\mathrm{Li}_{2} \mathrm{O}-\mathrm{P}_{2} \mathrm{O}_{5}[1,9,11]$. Hence, the introduction of a low $\mathrm{Fe}_{2} \mathrm{O}_{3}$ content $(\mathrm{y}<10)$ in the glass had no effect on the structural evolution. The IR spectra in the region between 1060 and $1100 \mathrm{~cm}^{-1}$ for the glasses with the composition $x \mathrm{Li}_{2} \mathrm{O}-\mathrm{yFe} \mathrm{O}_{2} \mathrm{O}_{3}-\chi \mathrm{P}_{2} \mathrm{O}_{5}$ with $\mathrm{x} / \chi=$ 0.54 and $(40-\mathrm{y}) \mathrm{Li}_{2} \mathrm{O}-\mathrm{yFe}{ }_{2} \mathrm{O}_{3}-60 \mathrm{P}_{2} \mathrm{O}_{5}$ confirmed the formation hypothesis of more small groups of $\mathrm{P}_{2} \mathrm{O}_{7}{ }^{4-}[28,29]$ when the $\mathrm{Fe}_{2} \mathrm{O}_{3}$ content increased in the glass-network. IR spectra of the binary glasses $\mathrm{Fe}_{2} \mathrm{O}_{3}-\mathrm{P}_{2} \mathrm{O}_{5}$ show that the band at $1290 \mathrm{~cm}^{-1}$ assigned to $v_{a}\left(\mathrm{PO}_{3}\right)[1,2,7,9]$ disappeared when the $\mathrm{Fe}_{2} \mathrm{O}_{3}$ content increased from $\mathrm{y}=10$ to $\mathrm{y}=28$, which assigns the band at $1070 \mathrm{~cm}^{-1}$ to $v_{\mathrm{s}}\left(\mathrm{PO}_{2}\right)$ $[1,9]$. These results agree with those obtained by X-ray diffraction. Hence, these results indicate that iron phosphate glasses which have a high $\mathrm{Fe}_{2} \mathrm{O}_{3}$ content are dominated by $\mathrm{P}_{2} \mathrm{O}_{7}{ }^{4-}$ and $\left(\mathrm{PO}_{3}\right)_{3}{ }^{3-}$ dimer units and contain a large number of Fe-O-P bonds which are responsible for theirexcellent chemical durability [16, 30-31]. The X-ray diffraction and IR spectra for the iron phosphate glasses depend considerably on the composition and glass structure. The changes in the characteristic features of these spectra follow the changes in the glass network and glass stability in addition to crystallization.

In the model of the samples glasses S1, S2 and S3 we noted a clear evolution in chemical resistance, probably caused by grain boundary resistance as a result of partial glass crystallization [26,32]. It was found that the introduction of a small amount of $\mathrm{Fe}_{2} \mathrm{O}_{3}(\mathrm{y}<10)$ in the glass don't changes the glass structure (Figure 9) and no significant effect on the chemical resistance. Looks like, it dissolves in the glass to give a homogeneous glass phase. When the iron oxide content reach $10 \mathrm{~mol} \%$, there are beginning of crystallites having a glassy phase dominant. Beyond $10 \%$ mole $\mathrm{Fe}_{2} \mathrm{O}_{3}$ content in the glass, the number of crystallites becomes increasingly important, and size becoming larger when approaching the boundary between the glass and the crystal (border).

\section{Conclusion}

The regular melting-quenching method allowed isolating a very large vitreous domain within the ternary system $\mathrm{Li}_{2} \mathrm{O}-\mathrm{P}_{2} \mathrm{O}_{5}-\mathrm{Fe}_{2} \mathrm{O}_{3}$. The structure and properties of lithium iron phosphate glasses were investigated using various techniques. Both X-ray diffraction and IR spectra indicate a structural evolution of glasses with composition in the ternary diagram of $\mathrm{Li}_{2} \mathrm{O}-\mathrm{Fe}_{2} \mathrm{O}_{3}-\mathrm{P}_{2} \mathrm{O}_{5}$. The results show that when the composition of the vitreous zone was moved away from the $\mathrm{P}_{2} \mathrm{O}_{5}$ point, the structure evolved toward one with a known crystallized composition neighborhood, $\mathrm{LiPO}_{3}, \mathrm{Fe}\left(\mathrm{PO}_{3}\right)_{3}, \quad \mathrm{Li}_{4} \mathrm{P}_{2} \mathrm{O}_{7}, \quad \mathrm{LiFeP}_{2} \mathrm{O}_{7}$. These glasses showed good chemical resistance for compositions with a high $\mathrm{Fe}_{2} \mathrm{O}_{3}$ content. The iron phosphorrus-oxygen network became stronger with an increase in 
the $\mathrm{Fe}_{2} \mathrm{O}_{3}$ content. The improved chemical resistance of iron phosphate glasses was attributed to the replacement of the easily hydrated P-O-P and Li-O-P bonds by corrosion-resistant $\mathrm{Fe}-\mathrm{O}-\mathrm{P}$ bonds. As the $\mathrm{Fe}_{2} \mathrm{O}_{3}$ content in the glass increased, the number of Fe-O-P bands also increased. The IR spectra indicates that iron phosphate glasses are dominated by $\mathrm{P}_{2} \mathrm{O}_{7}^{4-},\left(\mathrm{PO}_{3}\right)_{3}^{3-}$ dimer units and contain a large number of Fe-O-P bonds. The structural change caused an important tendency for crystallization which is the origin of the high chemical durability.

\section{REFERENCES}

[1] S. Aqdim, "Diplôme D'étude Supérieure de 3ème Cycle de Specialité," Faculty of ScienceRabat, University Mohammed V, Morocco, 1990.

[2] R. K. Brow, "The Structure of Simple Phosphate Glasses," Journal of Non-Crystalline Solids, Vol. 1, 2000, pp. 263-264.

[3] B. C. Sales, M. M. Abraham, J. B. Bates and L. A. Boatner, "Structural Properties of Lead-Iron Phosphate Glasses," Journal of Non-Crystalline, Vol. 71, 1985, pp. 103112. http://dx.doi.org/10.1016/0022-3093(85)90279-0

[4] B. C. Sales and L. A. Boatner, "Physical and Chemical Characteristics of Lead-Iron Phosphate Nuclear Waste Glasses," Journal of Non-Crystalline Solids, Vol. 79, 1986, pp. 83-116. http://dx.doi.org/10.1016/0022-3093(86)90040-2

[5] A. Musinu, G. Piccaluga and G. Pinna, "Structural Properties of Lead-Iron Phosphate Glasses by X-Ray Diffraction," Journal of Non-Crystalline Solids, Vol. 122, 1990, pp. 52-68. http://dx.doi.org/10.1016/0022-3093(90)90224-A

[6] P. A. Bingham, R. J. Hand, S. D. Forder and A. La Vaysierre, "Vitrified Metal Finishing Wastes: I. Composition, Density and Chemical Durability," Journal of Hazardous Materials, Vol. 119, 2005, pp. 125-133.

[7] D. E. Day, Z. Wu, C. S. Ray and P. Hrma, "Chemically Durable Iron Phosphate Glass Wasteforms," Journal of Non-Crystalline Solids, Vol. 241, 1998, pp. 1-12. http://dx.doi.org/10.1016/S0022-3093(98)00759-5

[8] B. C. Sales and L. A. Batner, "Lead-Iron Phosphate Glass: A Stable Storage Medium for High-Level Nuclear Waste," Sciences, Vol. 226, 1984, pp. 45-48. http://dx.doi.org/10.1126/science.226.4670.45

[9] M. Ouchetto, "Diplôme D'étude Supérieure de 3éme cycle," Faculty of Science Rabat, University Mohammed V, Morocco, 1983.

[10] H. Arbib, "Diplôme D’étude Supérieure de 3éme Cycle," Faculty of Science Rabat, Mohammed V, Morocco, 1987.

[11] M. Doreau, A. ABou El Anouar and G. Robert, "Domaine Vitreux, Structure et Conductivite Electrique des

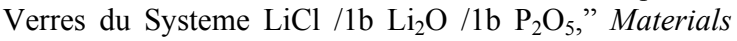
Research Bulletin, Vol. 15, 198, p. 285.

[12] M. Poulain, M. Cohnthansinh and J. Lucas, "Nouveaux Verres Fluores," Materials Research Bulletin, Vol. 12, No. 2, 1977, pp. 151-156.
http://dx.doi.org/10.1016/0025-5408(77)90157-X

[13] M. Imoka, “Advances in Glass Technologies," Plenum Press, New York, 1962.

[14] S. T. Reis, D. L. A. Faria, J. R. Martinelli, W. M. Pontuschka, D. E. Days and G. S. M. Partiti, "Structural Features of Lead Iron Phosphate Glasses," Journal of NonCrystalline Solids, Vol. 304, No. 1-3, 2002, pp. 188-194. http://dx.doi.org/10.1016/S0022-3093(02)01021-9

[15] T. Panier, J.-L. Souquet and M. Ribes, "Proche Environnement du fer et Conductivité Électrique de Verre du SystèmeNa $2 \mathrm{O} / \mathrm{SiO}_{2} / \mathrm{Fe}_{3} \mathrm{O}_{4} /$," Materials Research Bulletin, Vol. 20, 1985, p. 255.

[16] P. Bergo, S. T. Reis, W. M. Pontuschka, J. M. Prison and C. C. Motta, "Dielectric Properties and Structural Features of Barium-Iron Phosphate Glasses," Journal of Non-Crystalline Solids, Vol. 336, No. 3, 2004, pp. 159164. http://dx.doi.org/10.1016/j.jnoncrysol.2004.02.008

[17] C.-W. Kim and D. E. Day, "Immobilization of Hanford LAW in Iron Phosphate Glasses," Journal of Non-Crystalline Solids, Vol. 331, No. 1-3, 2003, pp. 20-31. http://dx.doi.org/10.1016/j.jnoncrysol.2003.08.070

[18] X. Fang, C. S. Ray, G. K. Marasingle and D. E. Day, "Properties of Mixed $\mathrm{Na}_{2} \mathrm{O}$ and $\mathrm{K}_{2} \mathrm{O}$ Iron Phosphate Glasses," Journal of Non-Crystalline Solids, Vol. 263264, 2000, pp. 293-298. http://dx.doi.org/10.1016/S0022-3093(99)00641-9

[19] G. K. Lewis, M. Marasinghe, M. Karabulut, C. S. Ray and D. E. Day, "Structural Future of Iron Phosphate Glasses," Journal of Non-Crystalline Solids, Vol. 222, 1997, p. 144.

[20] S. T. Reis, M. Karabubut and D. E. Day, "Chemical Durability and Structure of Zinc-Iron Phosphate Glasses," Journal of Non-Crystalline Solids, Vol. 292, No. 1-3, 2001, pp. 150-157. http://dx.doi.org/10.1016/S0022-3093(01)00880-8

[21] N. Amraoui, "Diplôme d'Etude Sup de $3^{\text {ème }}$ cycle," Mohammed V, Faculty of Science Rabat, Morocco, 1990.

[22] G. S. M. Partiti and J. Non-Cryst, "Structural Features of Lead Iron Phosphate Glasses," Solids, Vol. 304, No. 1-3, 2002, pp. 188-194. http://dx.doi.org/10.1016/S0022-3093(02)01021-9

[23] G. J. Exarhos, P. J. Miller and W. M. Risen, "Interionic Vibrations and Glass Transitions in Ionic Oxide Metaphosphate Glasses," The Journal of Chemical Physics, Vol. 60, 1974, p. 4145. http://dx.doi.org/10.1063/1.1680881

[24] W. Bues, H. W. Gerke and Z, Anorg, Allg. Chem., Vol. 288, 1956, p. 291.

[25] S. Aqdim, E. H. Sayouty and B. Elouadi, "Structural and Durability Investigation of the Vitreous Partb of the System (35-z) $\mathrm{Na}_{2} \mathrm{O}-\mathrm{zFe}_{2} \mathrm{O}_{3}-5 \mathrm{Al}_{2} \mathrm{O}_{3}-60 \mathrm{P}_{2} \mathrm{O}_{5}$," Eurasian Chemi-co-Technological Journal, Vol. 10, 2008, p. 9.

[26] A. Mogus-Milankovic, A. Sontic, S. T. Reis, F. Puric and D. E, Day, "Dielectric Behavior and Impedance Spectroscopy of Bismuth Iron Phosphate Glasses," Journal of Non-Crystalline Solids, Vol. 351, 2005, p. 3246.

[27] Y. M. Moustafa, K. EL-Egili, H. Doweidar and I. Abbas, 
"Structure and Electric Conduction of $\mathrm{Fe}_{2} \mathrm{O}_{3}-\mathrm{P}_{2} \mathrm{O}_{5}$ glasses," Physica B: Condensed Matter, Vol. 353, No. 1-2, 2004, pp. 82-91.

http://dx.doi.org/10.1016/j.physb.2004.09.004

[28] A. Mogus-Milankovic, A. Gajovic, A. Santic and D. E. Day, "Structure of Sodium Phosphate Glasses Containing $\mathrm{Al}_{2} \mathrm{O}_{3}$ and/or $\mathrm{Fe}_{2} \mathrm{O}_{3}$. Part I," Journal of Non-Crystalline Solids, Vol. 289, No. 1-3, 2001, pp. 204-213. http://dx.doi.org/10.1016/S0022-3093(01)00701-3

[29] M. Karabubut, G. K Marasinghe, P. G. Allen, C. H. Booth and M. Grimsditch, "Local Environment of Iron and Uranium Ions in Vitrified Iron Phosphate Glasses Studied by FeK and ULIII Edge X-ray Absorption Fine Structure Spectroscopy," Journal of Materials Research, Vol. 15, No. 9, 2000, pp. 1972-1984.

[30] A. Mogus-Milankovic, A. Santic, A. Gajovic and D. E. Day, "Electrical Properties of Sodium Phosphate Glasses
Containing $\mathrm{Al}_{2} \mathrm{O}_{3}$ and/or $\mathrm{Fe}_{2} \mathrm{O}_{3}$. Part II," Journal of Non-Crystalline Solids, Vol. 296, No. 1-2, 2001, pp. 5764. http://dx.doi.org/10.1016/S0022-3093(01)00889-4

[31] S. Aqdim, B. Elouadi and J.-M. Grenech, "Chemical Durability and Structural Approach of the Glass Series (40-y) $\mathrm{Na}_{2} \mathrm{O}-\mathrm{yFe} \mathrm{O}_{2}-5 \mathrm{Al}_{2} \mathrm{O}_{3} \quad 55 \mathrm{P}_{2} \mathrm{O}_{5}$-by IR, X-Ray Diffraction and Mössbauer Spectroscopy," Material Sciences and Engineering, Vol. 27, 2012, Article ID: 012003.

[32] E. Bernado, M. Varasso, F. Cadamuro and S. Hreglich, "Vitrification of Wastes and Preparation of Chemically Stable Sintered Glass-Ceramic Products," Journal of Non-Crystalline Solids, Vol. 352, 2006, pp. 4017-4023. http://dx.doi.org/10.1016/j.jnoncrysol.2006.07.001 